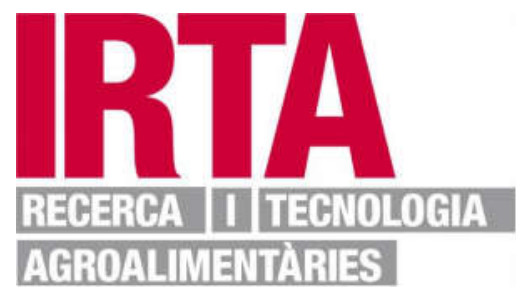

This is a post-peer-review, pre-copyedit version of an article published in Parasitology Research. The final authenticated version is available online at: https://doi.org/10.1007/s00436-018-5916-5 


\section{Tracking Toxoplasma gondii in freshwater ecosystems: interaction with the invasive American mink (Neovison vison) in Spain}

\section{AQ1}

Maria P. Ribas, AQ2 AQ3 1ø,2

Phone +34671366038

Email mariapuigribas@gmail.com

Sonia Almería, 3,2

Xavier Fernández-Aguilar, 1,2

Gabriel De Pedro, 4

Patricia Lizarraga, 5

Olga Alarcia-Alejos, 6

Rafael Molina-López, 7

Elena Obón, 7

Hojjat Gholipour, 8

Consuelo Temiño, 9

Jitender P. Dubey, 10

Oscar Cabezón, 1,2

1 Servei d'Ecopatologia de Fauna Salvatge (SEFaS), Departament de Medicina

i Cirurgia Animals, Universitat Autònoma de Barcelona

(UAB), 08193 Bellaterra, Spain 
${ }^{2}$ UAB, Centre de Recerca en Sanitat Animal (CReSA, IRTA-UAB), Campus de la Universitat Autònoma de Barcelona, 08193 Bellaterra, Spain

3

FDA, CFSAN, OARSA, DFEM, Laurel, MD, 20708 USA

4 Centro de Recuperación de Animales Silvestres de Valladolid, C/Cañada Real 308, 47008 Valladolid, Spain

5 Martioda Wildlife Rehabilitation Center, 01191 Martioda, Álava, Spain

6 Dirección General del Medio Natural, Consejería de Fomento y Medio Ambiente, Junta de Castilla y León, Rigoberto Cortejoso, 14, 47014 Valladolid, Spain

7 Centre de Fauna Salvatge de Torreferrussa, Direcció General del Medi Natural-Forestal Catalana, Generalitat de Catalunya, 08130 Sta. Perpètua de la Mogoda, Santa Perpètua de Mogoda, Spain

8 Department of Clinical Sciences, School of Veterinary Medicine, Shiraz University, PO Box: 71345-1731, Shiraz, Iran

9 Servicio Territorial de Medio Ambiente, Consejería de Fomento y Medio Ambiente, Junta de Castilla y León, Juan de Padilla s/n, 09006 Burgos, Spain

10 Animal Parasitic Diseases Laboratory, Agriculture Research Service, United States Department of Agriculture, Beltsville Agricultural Research Center, Beltsville, MD, 20705 USA

Received: 24 February 2018 / Accepted: 9 May 2018

\section{Abstract}

Water-borne transmission may play an important role in the epidemiology of Toxoplasma gondii. Mammals closely related to freshwater ecosystems, such as the American mink (Neovison vison), are potentially valuable sentinels for $T$. gondii. To assess the importance of freshwater ecosystems in T. gondii epidemiology, sera of 678 American minks collected during the 2010 to 2015 
Spanish national eradication campaigns were tested for the presence of $T$. gondii antibodies using the modified agglutination test (MAT, cut-off 1:25). A high prevalence of samples, $78.8 \%\left(\mathrm{CI}_{95 \%}: 75.5-81.8\right)$, were seropositive. In addition, a specific real-time PCR was performed in 120 brain samples and the parasite DNA was detected in $9.2 \%\left(\mathrm{CI}_{95 \%}: 5.2-15.7\right)$. Significant differences in seroprevalence were detected among bioregions, with the highest levels detected in coastal areas, and by age. The higher seroprevalence observed in older animals (80.0\% adults versus $68.7 \%$ juveniles) confirms the importance of the horizontal transmission. These results indicate a widespread presence of $T$. gondii oocysts in freshwater ecosystems from Spain and further support the importance of water-borne transmission in the epidemiology of $T$. gondii.

\section{Keywords}

American mink (Neovison vison)

Seroprevalence

Toxoplasma gondii

Wildlife disease

Zoonosis

Section Editor: Larissa Howe

\section{Introduction}

Toxoplasma gondii is an intracellular protozoan parasite of worldwide distribution. Wild and domestic felines are the definitive hosts and excrete the environmentally resistant oocysts. Humans and potentially all warm-blooded species can become infected acting as intermediate hosts (Dubey 2010). Both the intermediate and the definitive host can acquire the infection via one of the following routes: (1) horizontally by oral ingestion of sporulated oocysts from the environment, (2) horizontally by ingestion of tissue cysts contained in the intermediate host, or (3) vertically by transplacental transmission of tachyzoites (Dubey 2010).

Water-borne transmission of $T$. gondii is a growing concern (Ahlers et al. 2015). Although traditionally considered a parasite of terrestrial habitats, recent reports 
have identified $T$. gondii in seals, dolphins, and other marine and freshwater mammals, including the American mink (Neovison vison) (reviewed by Chadwick et al. 2013). Sporulated oocysts of $T$. gondii are resistant to environmental conditions and remain infective up to 54 months in freshwater at $4{ }^{\circ} \mathrm{C}$ (Dubey 1998) and for 24 months in seawater (Lindsay and Dubey 2009). Human settlements favor high felid densities that can excrete oocysts into sewage waters and contaminate aquatic ecosystems (VanwWormer et al., 2013a). In fact, freshwater runoff has been considered as one of the main sources of $T$. gondii strains from land to coastal anthropogenic environments (Miller et al. 2002). The contamination of continental water with sporulated oocysts can be a threat for freshwater and marine mammals, as well as birds linked to aquatic ecosystems (Cabezón et al. 2004; Cabezón et al. 2016; Chadwick et al. 2013; Dubey et al. 2003; Jensen et al. 2010; Sulzner et al. 2012). Contamination of near-shore waters by $T$. gondii oocysts may negatively affect the survival of several sensitive marine mammals such as southern sea otters (Enhydra lutris) in the USA (Kreuder et al. 2003; Conrad et al. 2005) and the parasite represents the second most common infectious cause of death in dolphins from the Mediterranean Seasea (Domingo et al. 1992; Resendes et al. 2002). Contaminated run-off has also been atso-implicated in T. gondii outbreaks in humans (Jones and Dubey 2010).

$\mathrm{AQ} 4$

Mammals from a high trophic level in aquatic ecosystems can be good sentinels for the detection of pathogens (Bossart 2011; Moura et al. 2014). In this sense, serological and molecular studies on mammal species can be useful to provide a better understanding of the impact of human populations on aquatic ecosystems. The American mink (Neovison vison) is a semi-aquatic invasive species with a wide distribution throughout the North and Central Iberian Peninsula. This European-invasive mustelid species-has opportunistic feeding habits, but is considered a predominantly freshwater carnivore. This Europan-ine mustelid This species is a significant competitor that compromises the viability of populations of native species such as the European mink (Mustela lutreola) (Maran et al. 1998; Sidorovich et al. 1999), which is considered Critically Endangered by the International Union for Conservation of Nature (Maran et al. 2011). Eradication campaigns of American minks in Spain have been conducted in order to reduce their populations (MAGRAMA 2014) and samples are easily 
available. Due to its close relation to freshwater ecosystems, we hypothesized that the American mink is an appropriate sentinel species for pathogens of great importance in public and animal health such as $T$. gondii.

The aim of the present study was to analyze the seroprevalence and infection of T. gondii in the invasive American mink, in order to assess the environmental contamination of freshwater ecosystems from Spain and to confirm the importance of water-borne transmission in the epidemiology of T. gondii.

\section{Materials and methods}

\section{Animal samples}

American minks were captured during the 2010 to 2015 Spanish national eradication campaigns. Captures were performed using baited boxtraps and animals were euthanized with an intramuscular injection of ketaminemedetomidine followed by an intracardiac injection of pentobarbital sodium (MAGRAMA 2014). All capture, data collection, and sampling procedures in the field, as well as euthanasia methods, were approved as part of the national eradication control programs for the American mink in Spain. Fieldwork permits were authorized by the relevant administrations from Generalitat de Catalunya, Junta de Castilla-y-León, La Rioja, and País Vasco.

Serum samples $(n=678)$ were obtained from four Autonomous Communities in the North of Spain (Castilla y León, La Rioja, Basque Country, and Catalonia) (Table 1). The regions correspond with the two main river basins (Ebro and Duero) in North Spain. Blood was collected by intracardiac puncture or from the thoracic cavity of euthanized animals. Blood was centrifuged to separate the serum and was stored at $-20{ }^{\circ} \mathrm{C}$ until the analysis was performed. Brain tissue was also collected in sterile tubes and stored at $-20^{\circ} \mathrm{C}$. The location of each captured animal was registered and each individual was examined to define sex and age stage (juvenile $<1$ year and adult $>1$ year) according to size, sexual maturity, and dental characteristics.

Table 1 The Table 1 contains mainly information of results. May be better placed it in the Results section.

Toxoplasma gondii seroprevalence (MAT $\geq 1: 25$ ) in American minks (Neovison vison) by the variables considered in this study. Statistically significant differences when 
different letters $(a, b)$ within earch categoryies $(p$ value $<0.05)$ are shown with different letters $(\mathrm{a}, \mathrm{b})$.

\begin{tabular}{|c|c|c|}
\hline \multicolumn{2}{|c|}{ Category } & $\begin{array}{l}\text { Positive/examined ( } \%, \mathbf{C} \text { Please note that a is already } \\
\text { used to indicate significant differences. I have changed the } \\
\text { symbol by } * \text {, but could be any other. } \mathbf{I}^{\mathbf{f}^{*}} \text { ) }\end{array}$ \\
\hline \multirow{4}{*}{$\begin{array}{l}\text { Autonomous } \\
\text { community }\end{array}$} & Catalonia & $38 / 46(82.6,69.3-90.9)$ \\
\hline & $\begin{array}{l}\text { Castilla y } \\
\text { León }\end{array}$ & $403 / 510(79.0,75.3-82.3)$ \\
\hline & La Rioja & $48 / 67(71.6,59.9-81.0)$ \\
\hline & $\begin{array}{l}\text { Basque } \\
\text { Country }\end{array}$ & $45 / 55(81.8,69.7-89.8)$ \\
\hline \multirow{2}{*}{ Bioregion } & 2 & $510 / 653(78.1,74.8-81.1)^{\mathrm{a}}$ \\
\hline & 5 & $22 / 23(95.7,79.0-99.8)^{b}$ \\
\hline \multirow{2}{*}{ River basin } & Duero & $360 / 460(78.3,74.3-81.8)$ \\
\hline & Ebro & $119 / 161(73.9,66.6-80.1)$ \\
\hline \multirow{2}{*}{ Sex } & Male & $289 / 370(78.1,73.6-82.0)$ \\
\hline & Female & $182 / 239(76.2,70.4-81.1)$ \\
\hline \multirow{2}{*}{ Age stage } & Juvenile & $103 / 150(68.7,60.9-75.5)^{\mathrm{a}}$ \\
\hline & Adult & $385 / 481(80.0,76.2-83.4)^{b}$ \\
\hline
\end{tabular}

\section{Study area}

The great diversity of habitats and climates within Spainthe Iberian Peninsula can be simplified to five different bioregions (RASVE 2011). In order to consider the ecological features, each region was ascribed to its corresponding bioregion. Consequently, bioregion 2 (Northern plateau) includes León, Palencia, and Burgos provinces (Castilla y León); La Rioja (La Rioja); Álava province (Basque Country); and Lleida province (Catalonia). Likewise, bioregion 5 (Southeastern coast) includes Barcelona and Girona provinces (Catalonia) (Fig. 1). 
Fig. 1

Map with the location of the serum samples (black spots) on the main rivers of Spainthe Iberian Peninsula (black lines). Bioregions 2 and 5 are shown in striped and spotted patterns, respectively. Bioregions not included in the study (1 and 4) are shown in different gray colors (QGIS 2.14 Essen 2016)

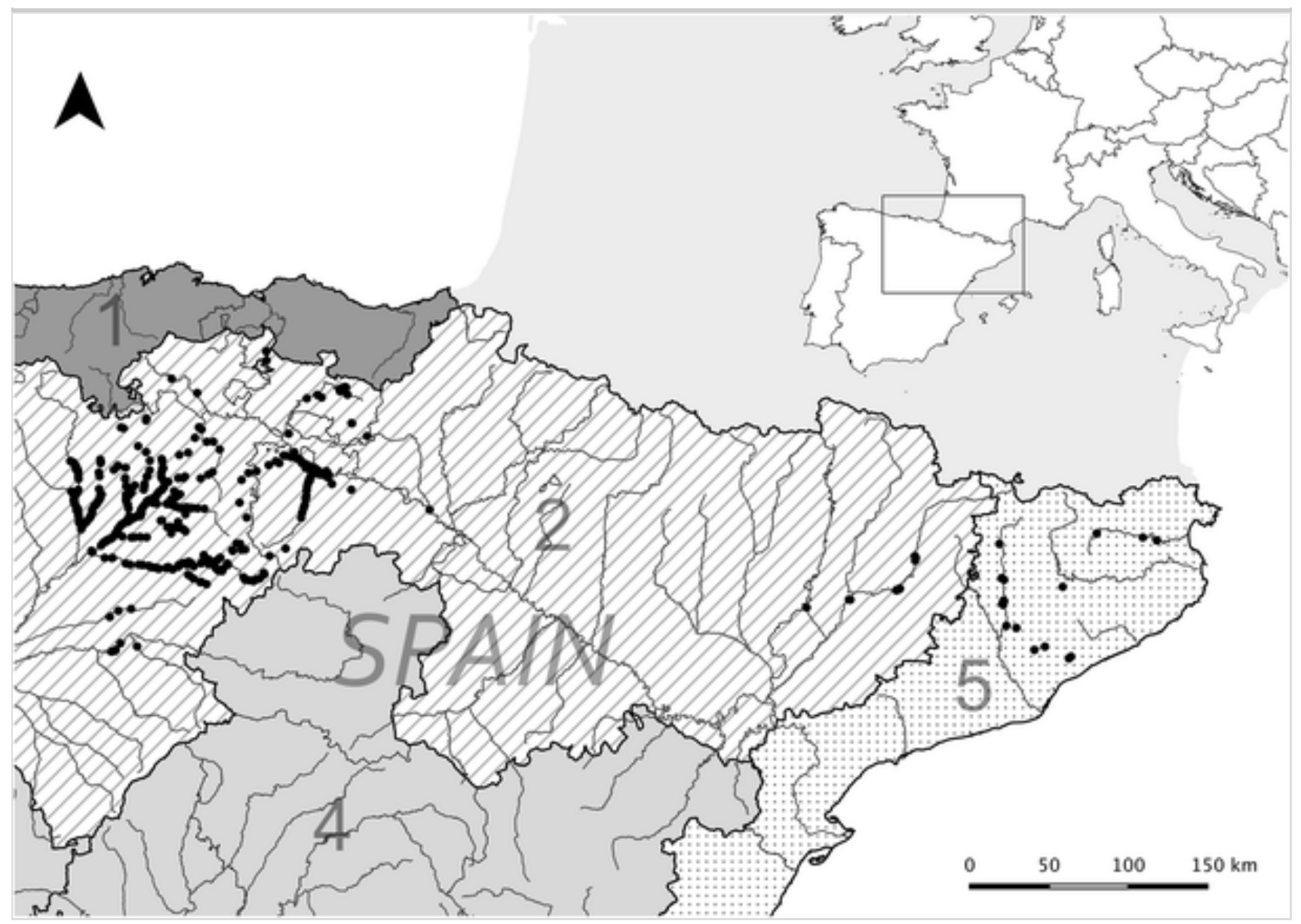

\section{Serological analysis}

Sera were tested by the modified agglutination test (MAT) to detect IgG antibodies against $T$. gondii at 1:25, 1:50, 1:100, and 1:500 dilutions (Dubey and Desmonts 1987). Positive and negative controls were also included in all tests. This technique has demonstrated a high sensitivity and specificity and has been previously evaluated in several wildlife species (Dubey et al. 2004), including mustelids (Sobrino et al. 2007). Titers of 1:25 or higher were considered positive and doubtful results were reexamined. Although hemolysis does not represent a problem (Dubey et al. 2003), hemolytic sera were filtered 
using sterile $0.2-\mu \mathrm{m}$ microfilters prior to the test.

\section{DNA extraction and detection}

The brain tissues of 120 American minks from which samples were available were mechanically homogenized, and DNA was extracted using the commercial kit NucleoSpin®Tissue (Macherey-Nagel) for genomic DNA following the manufacture's protocol. Real-time PCR (qPCR) specific for T. gondii was performed based on the 529-bp DNA fragment that is repeated 200-300 times in the $T$. gondii genome (Homan et al. 2000). The primers used were Toxo-SE (900 nM, 5'-AGGCGAGGGTGAGGATGA) and Toxo-AS (900 nM, 5'TCGTCTCGTCTGGATCGCAT) and the probe Toxotaqman (300 nM, 5'-6FAM-CGACGAGAGTCGGAGAGGGAGAAGATGT--BHQ1). PCR reactions were performed in a $25-\mu 1$ reaction mixture containing $2 \mu \mathrm{l}$ of sample, $0.45 \mu \mathrm{l}$ of each primer, $0.15 \mu \mathrm{l}$ of probe, $12.5 \mu \mathrm{l}$ of TaqMan ${ }^{\circledR} 2 \times$ Universal PCR MasterMix (Applied Biosystem, Warrington, UK), and $9.45 \mu \mathrm{l}$ of sterile water. Amplification was performed on Applied Biosystems ${ }^{\circledR} 7500$ Fast Real-time PCR system by 2 min at $50{ }^{\circ} \mathrm{C}$ and $10 \mathrm{~min}$ at $95{ }^{\circ} \mathrm{C}$ initial incubation followed by 40 cycles of $15 \mathrm{~s}$ at $95{ }^{\circ} \mathrm{C}$ and $1 \mathrm{~min}$ at $61{ }^{\circ} \mathrm{C}$. Positive and negative controls were included in each analysis.

\section{Statistical analysis}

Prevalence of antibodies against $T$. gondii was estimated from the ratio of positive to the total number of samples with the Wilson confidence intervals of $95 \%$. Association between seropositivity and independent variables

(Autonomous Community, bioregion, river basin, sex, and age) was assessed using a Pearson Chi-squared test or Fisher's exact test when observations/category were $<6$. Year of sampling was excluded from statistic analysis due to large differences in the number of samples for each year. No statistical analysis was performed on PCR results due to the low number of positive samples observed. The differences were considered statistically significant when $P \leq 0.05$. Analyses were performed using the R Statistical Software 3.1.3 (R Development Core Team 3.1.3, 2015).

\section{Results}

Seroprevalence levels of T. gondii in American mink-in each category of the 
American minks are presented in Table 1 and locations of captured individuals are shown in Fig. 1. Overall seroprevalence was $78.8 \%\left(534 / 678, \mathrm{CI}_{95 \%}: 75.5-\right.$ 81.7 ), with titers of $1: 25$ in $11.2 \%$ of the samples, $1: 50$ in $7.3 \%$ of the samples, $1: 100$ in $32.6 \%$ of the samples, and $1: 500$ in $48.9 \%$ of the samples. No statistically significant differences in $T$. gondii seroprevalence were observed among Autonomous Communities, river basins, and sex of the animals. Statistically significant differences were found among bioregions ( $p$ value $=$ 0.0399 ) with an odds ratio (OR) of 6.16 in bioregion 5 versus bioregion 2 and among age categories ( $p$ value $=0.0052)$ with an OR of 0.55 in adults versus juveniles.

T. gondii DNA was detected by qPCR in 11 of the 120 samples analyzed (9.2\%, CI 5.2-15.7). Six of the PCR-positive samples corresponded to American minks captured in the province of Burgos (Castilla y León) located in the Duero river basin, while three positive samples were from La Rioja and two samples were from Alava (Basque Country), located in the Ebro river basin. Eight PCRpositive minks were also positive teby the MAT with titers of $\geq 1: 500$ (four minks) and 1:100 (four minks) and one PCR-positive mink was negative by serologic analysis. In two animals, the serological status was unknown. Three PCR-positive animals were juveniles while eight PCR-positive samples were from adults. Two PCR-positive samples corresponded to females and nine PCRpositive samples were from males.

\section{Discussion}

The high seroprevalence and molecular detection of the parasite in the brain indicate a frequent exposure of American minks to $T$. gondii. No significant differences were observed among the four different Autonomous Communities sampled and the two main river basins in Spain, indicating that the parasite was widespread in freshwater ecosystems from Spain. Similar seroprevalences (70\%) were described in a study of American minks from Chile (Sepúlveda et al. 2011). Despite most of $T$. gondii studies being focused on terrestrial hosts, these results suggest that the parasite can be commonly found in inland aquatic systems, as demonstrated also in marine coastal areas (Miller et al. 2008), and propose water courses as an important mechanism of oocysts spread.

Different ecological and climatic features of each bioregion or differences in 
definitive host densities may explain the observed significant differences of seroprevalence among bioregions. Bioregion 5 mainly comprises the coastal areas of Catalonia, which has higher humidity and higher human density. Human settlements constitute artificial environments with a high density of domestic felids that excrete oocysts (VanwWormer et al., z013ab). The importance of human populations in T. gondii epidemiology is reinforced by the growing number of feral cat populations, the elevated number of oocysts excreted by each infected cat, the long-term viability of the oocysts, and the fact that a single oocyst can be infective for several species (reviewed by Torrey and Yolken 2013). Several studies have suggested a positive relationship between high $T$. gondii seroprevalences in suburban wildlife and elevated feral cat densities (Miller et al. 2002; Sepúlveda et al. 2011; VanwWormer et al., $2013 \mathrm{ab}$ ). To the authors' knowledge, no actual census of feral cat populations exists in the areas included in the present study. Future studies should be centered on determining factors that may influence the density of definitive hosts and the persistence and spread of oocysts, which mayto explain the observed T. gondii variability in freshwater ecosystems.

Due to the feeding habits and the repetitive ingestion of tissue cysts in prey, carnivores and omnivores are more likely to be infected with T. gondii than herbivores (Hejlícek et al. 1997). The high seroprevalence in American minks was only comparable to the elevated seroprevalence of $T$. gondii previously reported in definitive hosts in Spain. Feral cats in Majorca, Balearic Islands, were highly seropositive $(84.7 \%, n=59)$, one of the highest levels reported worldwide in this species and the highest observed in Europe to date (Millán et al. 2009a). Similar results were observed in domestic cats in other areas of Spain (45 to 50\% Gauss et al. 2003; Millán et al. 2009b, respectively) and in Iberian lynx (Lynx pardinus) $(62.8 \%, n=29)$ (García-Bocanegra et al. 2010) using the same serological technique. Several mustelids species, including Eurasian otters (Lutra lutra) in Spain (Sobrino et al. 2007), have also shown high seroprevalences. According to the high prevalences observed, mammals closely related to aquatic ecosystems may have a high risk of exposure to the parasite suggesting that water-borne transmission of oocysts may be of great importance for $T$. gondii epidemiology.

Juvenile animals were $50 \%$ less likely to be infected than adults. Given the lifelong persistence of $T$. gondii IgG antibodies in healthy individuals, 
seroprevalence by MAT reflects the lifelong exposure to the parasite (Remington et al. 2004). Increased contact by age indicates that horizontal transmission was the main route of T. gondii infection for the American mink. Horizontal transmission can occur by consumption of environmental oocysts or by ingestion of cysts in tissues of prey. The diet of the American mink was not evaluated in the animals of the present study. However, previous work in the Iberian Peninsula showed that aquatic prey (fish and crayfish) represent 45.9$71.4 \%$ of the American mink's diet depending on the season (Melero et al. 2008). Ectothermic (cold-blooded) animals such as fish or crayfish reportedly do not develop tissue cysts of $T$. gondii, and consequently, their role in the epidemiology of the parasite is still unknown. However, some aquatic invertebrates such as bivalves or filter-feeding fish are able to remove sporulated $T$. gondii oocysts from seawater and retain their infectivity (Lindsay et al. 2004; Fayer et al. 2004; Massie et al. 2010). These filter-feeding aquatic animals could potentially act as mechanical vectors transporting oocysts and as a source of infection for freshwater and marine animals and for humans. In fact, the consumption of contaminated invertebrate prey was suspected as the vehicle for the exposure of southern sea otters (Enhydra lutris nereis) to T. gondii (Miller et al. 2008). Another route of exposure to the parasite would be the ingestion of sporulated oocysts present in water. Contamination of waterways could be facilitated by the hydrophilic nature and negative charge of $T$. gondii oocysts in freshwater, which could enhance transportation through water runoff (Shapiro et al. 2009, 2012). The high seroprevalence of $T$. gondii in a predominantly piscivorous freshwater mammal suggests widespread fecal contamination of freshwater ecosystems with oocysts. However, minks can also be opportunistic predators and occasionally take mammals and birds, and therefore become infected via ingestion of prey with tissue cysts of T. gondii. Therefore, confirmation of the specific route of exposure in minks is difficult.

The infection of T. gondii in American minks was also supported by the presence of DNA in tissues analyzed by real-time PCR. Most studies of $T$. gondii in Spain have been based on serology rather than molecular detection of the parasite. The fact that only $10 \%$ of the analyzed samples were PCR-positive compared to the high seroprevalence levels observed was probably due to the non-homogenous distribution of T. gondii tissue cysts and the small sample used for DNA detection. Burrells et al. (2013) also described similar results by 
detection of $T$. gondii DNA in 20\% (13/65) of brain tissues from American mink in the UK.

Due to the eradication programs in Spain and Europe, the American mink is potentially a useful sentinel species to track water-borne pathogens of importance in public and animal health, such as $T$. gondii. Although $T$. gondii infection was confirmed in this species by PCR, no mortality cases associated with $T$. gondii in mustelids have been confirmed in the Iberian Peninsula. Outbreaks and clinical cases have been observed in farmed American minks (Frank 2001; Śmielewska-Łoś and Turniak 2004) and even in free-feral minks (Jones et al. 2006). Surveillance of the invasive American mink for T. gondii is valuable because of conservation concerns for the European mink and the Eurasian otter, and also because of its suitability as a sentinel for freshwater contamination with oocysts. Anthropogenic activities and demographic changes are modifying the dispersion and emergence patterns of pathogens (Jones et al. 2008). Additionally, human coastal development can change populations of felids, increase $T$. gondii oocysts in water runoff, and disrupt disease dynamics, increasing the importance of a holistic approach to the study of this parasite (VanWormer et al. 2013a). Understanding the epidemiology of T. gondii in an ecosystem context is critical to human and animal health as this parasite represents a good example of the complexity in multi-host pathogen transmission. As populations of humans and their companion animals grow, the impacts of fecal contamination on public and wildlife health are likely to increase (Fayer et al. 2004; Chadwick et al. 2013). This study supports the growing body of evidence that freshwater ecosystems have an importante role on T. gondii transmission and its relevance on public helath should be further considered.

\section{Conclusions}

The high exposure of $T$. gondii detected in American minks indicates a widespread presence of the parasite in freshwater ecosystems in Spain. Horizontal transmission is the main route of infection for the American minks, strengthening the importance of water-borne transmission of $T$. gondii oocysts on its epidemiology. The highest seroprevalence was found in coastal regions, which are associated with areas of higher human density, and may reflect the influence of human settlements in the dynamics of the parasite. The invasive 
American mink is a good sentinel species for $T$. gondii contamination in freshwater habitats.

\section{Acknowledgements}

The authors would like to thank the staff of the wildlife rehabilitation centres (WRC) of Burgos, especially to Ms. Nerea Falagán (Castilla-y-León), the WRCMartioda (Basque Country) and WRC-La Fombera (La Rioja) for their help in the sample collection. Also, the authors would like to thank the people from of Castilla-y-León, La Rioja, Diputación Foral de Álava and Ministerio de Medio Ambiente governments, to the Asociación Visón Europeo, Tragsatec and to the Fundación Biodiversidad that have been directly or indirectly involved in the fieldwork. Most of the samples were collected in several Spanish territories within the National Program for control the American mink. This study was partly financied by FEDER and Spanish MINECO grant (AGL2012-39830-C0201/02) and LIFE LUTREOLA SPAIN (LIFE 13 NAT/ES/001171). The authors are also very grateful for the technical contribution of Asunción Gómez from TRAGSATEC and Madis Pödra from Asociación Visón Europeo.

Compliance with ethical standards

Conflict of interest The authors declare that they have no conflict of interest.

\section{References}

\section{AQ5}

Ahlers AA, Mitchell MA, Dubey JP, Schooley RL, Heske EJ (2015) Risk factors for Toxoplasma gondii exposure in semiaquatic mammals in a freshwater ecosystem. J Wildl Dis 51:488-492. https://doi.org/10.7589/201403-071

Bossart GD (2011) Marine mammals as sentinel species for oceans and human health. Vet Pathol 48:676-690.

https://doi.org/10.5670/oceanog.2006.77

Burrells A, Bartley PM, Zimmer IA et al (2013) Evidence of the three main clonal toxoplasma gondii lineages from wild mammalian carnivores in the 
UK. Parasitology 140:1768-1776.

https://doi.org/10.1017/S0031182013001169

Cabezón O, Resendes AR, Domingo M, Raga JA, Agustí C, Alegre F, Mons JL, Dubey JP, Almería S (2004) Seroprevalence of Toxoplasma gondii antibodies in wild dolphins from the Spanish Mediterranean coast. J Parasitol 90:643-644

Cabezón O, Cerdà-Cuéllar M, Morera V, García-Bocanegra I, González-Solís J, Napp S, Ribas MP, Blanch-Lázaro B, Fernández-Aguilar X, Antilles N, López-Soria S, Lorca-Oró C, Dubey JP, Almería S (2016) Toxoplasma gondii infection in seagull chicks is related to the consumption of freshwater food resources. PLoS One 11:1-11. https://doi.org/10.1371/journal.pone.0150249

Chadwick E, Cable J, Chinchen A et al (2013) Seroprevalence of Toxoplasma gondii in the Eurasian otter (Lutra lutra) in England and Wales. Parasit Vectors 6:75. https://doi.org/10.1186/1756-3305-6-75

Conrad P, Miller M, Kreuder C et al (2005) Transmission of Toxoplasma: clues from the study of sea otters as sentinels of Toxoplasma gondii flow into the marine environment. Int J Parasitol 35:1155-1168.

https://doi.org/10.1016/j.ijpara.2005.07.002

Domingo M, Visa J, Pumarola M, Marco AJ, Ferrer L, Rabanal R, Kennedy S (1992) Pathologic and Immunocytochemical studies of morbillivirus infection in striped dolphins (Stenella coeruleoalba). Vet Pathol 29:1-10

Dubey JP (1998) Toxoplasma gondii oocyst survival under defined temperatures. J Parasitol 84:862-865

Dubey JP (2010) Toxoplasmosis of animals and humans, 2nd edn. CRC Press, Boca Raton, Florida

Dubey JP, Desmonts G (1987) Serological responses of equids fed Toxoplasma gondii oocysts. Equine Vet J 19:337-339

Dubey JP, Zarnke R, Thomas N et al (2003) Toxoplasma gondii, Neospora 
caninum, Sarcocystis neurona, and Sarcocystis canis-like infections in marine mammals. Vet Parasitol 116:275-296. https://doi.org/10.1016/S03044017(03)00263-2

Dubey JP, Graham DH, De YRW et al (2004) Molecular and biologic characteristics of Toxoplasma gondii isolates from wildlife in the United States. J Parasitol 90:67-71

Fayer R, Dubey JP, Lindsay DS (2004) Zoonotic protozoa: from land to sea. Trends Parasitol 20:531-536. https://doi.org/10.1016/j.pt.2004.08.008

Frank RK (2001) An outbreak of toxoplasmosis in farmed mink (Mustela vison S.). J Vet Diagn Investig 13:245-249.

https://doi.org/10.1177/104063870101300310

García-Bocanegra I, Dubey JP, Martínez F, Vargas A, Cabezón O, Zorrilla I, Arenas A, Almería S (2010) Factors affecting seroprevalence of Toxoplasma gondii in the endangered Iberian lynx (Lynx pardinus). Vet Parasitol 167:3642. https://doi.org/10.1016/j.vetpar.2009.09.044

Gauss CBL, Almería S, Ortuño A, Garcia F, Dubey JP (2003)

Seroprevalence of toxoplasma gondii antibodies in domestic cats from Barcelona, Spain. J Parasitol 89:1067-1068

Hejlícek K, Literák I, Nezval J (1997) Toxoplasmosis in wild mammals from the Czech Republic. J Wildl Dis 33:480-485. https://doi.org/10.7589/0090$3558-33.3 .480$

Homan W, Vercammen M, De Braekeleer J, Verschueren H (2000) Identification of a 200- to 300-fold repetitive $529 \mathrm{bp}$ DNA fragment in Toxoplasma gondii, and its use for diagnostic and quantitative PCR. Int J Parasitol 30:69-75. https://doi.org/10.1016/S0020-7519(99)00170-8

Jensen SK, Aars J, Lydersen C, Kovacs KM, Åsbakk K (2010) The prevalence of Toxoplasma gondii in polar bears and their marine mammal prey: evidence for a marine transmission pathway? Polar Biol 33:599-606. https://doi.org/10.1007/s00300-009-0735-x 
Jones JL, Dubey JP (2010) Waterborne toxoplasmosis - recent developments. Exp Parasitol 124:10-25. https://doi.org/10.1016/j.exppara.2009.03.013

Jones YL, Fitzgerald SD, Sikarske JG, Murphy A, Grosjean N, Kiupel M (2006) Toxoplasmosis in a free-ranging mink. J Wildl Dis 42:865-869. https://doi.org/10.7589/0090-3558-42.4.865

Jones KE, Patel NG, Levy MA, Storeygard A, Balk D, Gittleman JL, Daszak P (2008) Global trends in emerging infectious diseases. Nature 451:990-993. https://doi.org/10.1038/nature06536

Kreuder AC, Miller MA, Jessup DA et al (2003) Patterns of mortality in southern sea otters (Enhdra lutris nereis) from 1998 - 2001. J Wildl Dis 39:495-509

Lindsay DS, Dubey JP (2009) Long-term survival of Toxoplasma gondii sporulated oocysts in seawater. J Parasitol 95:1019-1020. https://doi.org/10.1645/GE-1919.1

Lindsay DS, Collins MV, Mitchell SM, Wetch CN, Rosypal AC, Flick GJ, Zajac AM, Lindquist A, Dubey JP (2004) Survival of Toxoplasma gondii oocysts in eastern oysters (Crassostrea virginica). J Parasitol 90:1054-1057. https://doi.org/10.1645/GE-296R

MAGRAMA (2014) Estrategia de gestión, control y erradicación del visón americano (Neovison vison) en España. Ministerio de Agruicultura, Alimentación y Medio Ambiente. Gobierno de España

Maran T, Macdonald D, Kruuk H (1998) The continuing decline of the European mink, Mustela lutreola: evidence for the intraguild aggression hypothesis. Behav Ecol Riparian Mamm

Maran T, Skumatov D, Palazón S, et al (2011) Mustela lutreola. The IUCN Red List of Threatened Species: e.T14018A4382176

Massie GN, Ware MW, Villegas EN, Black MW (2010) Uptake and transmission of Toxoplasma gondii oocysts by migratory, filter-feeding fish. 
Vet Parasitol 169:296-303. https://doi.org/10.1016/j.vetpar.2010.01.002

Melero Y, Palazón S, Bonesi L, Albez JGOS (2008) Feeding habits of three sympatric mammals in NE Spain : the American mink, the spotted genet, and the Eurasian otter. Acta Theriol (Warsz) 53:263-273

Millán J, Cabezón O, Pabón M, Dubey JP, Almería S (2009a) Seroprevalence of Toxoplasma gondii and Neospora caninum in feral cats (Felis silvestris catus) in Majorca, Balearic Islands, Spain. Vet Parasitol 165:323-326. https://doi.org/10.1016/j.vetpar.2009.07.014

Millán J, Candela MG, Palomares F, Cubero MJ, Rodríguez A, Barral M, de la Fuente J, Almería S, León-Vizcaíno L (2009b) Disease threats to the endangered Iberian lynx (Lynx pardinus). Vet J 182:114-124. https://doi.org/10.1016/j.tvj1.2008.04.005

Miller MA, Gardner IA, Kreuder C, Paradies DM, Worcester KR, Jessup DA, Dodd E, Harris MD, Ames JA, Packham AE, Conrad PA (2002) Coastal freshwater runoff is a risk factor for Toxoplasma gondii infection of southern sea otters (Enhydra lutris nereis). Int J Parasitol 32:997-1006

Miller MA, Miller WA, Conrad PA, James ER, Melli AC, Leutenegger CM, Dabritz HA, Packham AE, Paradies D, Harris M, Ames J, Jessup DA, Worcester K, Grigg ME (2008) Type X Toxoplasma gondii in a wild mussel and terrestrial carnivores from coastal California: new linkages between terrestrial mammals, runoff and toxoplasmosis of sea otters. Int J Parasitol 38:1319-1328. https://doi.org/10.1016/j.ijpara.2008.02.005

De Moura JF, Hauser-davis RA, Lemos L et al (2014) Guiana dolphins (Sotalia guianensis) as marine ecosystem sentinels: ecotoxicology and emerging diseases. Rev Environ Contam Toxicol 228. https://doi.org/10.1007/978-3-319-01619-1

AQ6

QGIS 2.14 Essen (2016) QGIS development team. QGIS Geogaphic information system [internet]. Open source geospatial foundation project. 2016. Available: http://qgis.osgeo.org 
R Development Core Team 3.1.3. (2015) R development Core team 3.1.3. A language and environment for statistical computing. $\mathrm{R}$ foundation for statistical computing

RASVE (2011) Ministerio de Medio Ambiente Medio Rural y Marino (MAPYA) Available:

http://rasve.mapa.es/publica/programas/NORMATIVA\%20Y\%20PROGRAMAS\%

Remington JS, Thulliez P, Montoya JG (2004) Recent developments for diagnosis of toxoplasmosis. J Clin Microbiol 42:941-945.

https://doi.org/10.1128/JCM.42.3.941

Resendes AR, Almeria S, Dubey JP et al (2002) Disseminated toxoplasmosis in a Mediterranean pregnant Risso 's dolphin (Grampus griseus) with Transplacental fetal infection. J Parasitol 88:1029-1032

Sepúlveda M, Muñoz-Zanzi C, Rosenfeld C et al (2011) Toxoplasma gondii in feral American minks at the Maullín river, Chile. Vet Parasitol 175:60-65. https://doi.org/10.1016/j.vetpar.2010.09.020

Shapiro K, Largier J, Mazet JAK, Bernt W, Ell JR, Melli AC, Conrad PA (2009) Surface properties of Toxoplasma gondii oocysts and surrogate microspheres. Appl Environ Microbiol 75:1185-1191.

https://doi.org/10.1128/AEM.02109-08

Shapiro K, Silver MW, Largier JL, Conrad PA, Mazet JAK (2012) Association of Toxoplasma gondii oocysts with fresh, estuarine, and marine macroaggregates. Limnol Oceanogr 57:449-456.

https://doi.org/10.4319/1o.2012.57.2.0449

Sidorovich V, Kruuk H, Macdonald DW (1999) Body size, and interactions between European and American mink (Mustela lutreola and M. vison) in Eastern Europe. J Zool 248:521-527

Śmielewska-Łoś E, Turniak W (2004) Toxoplasma gondii infection in polish farmed mink. Vet Parasitol 122:201-206.

https://doi.org/10.1016/j.vetpar.2004.02.003 
Sobrino R, Cabezón O, Millán J, Pabón M, Arnal MC, Luco DF, Gortázar C, Dubey JP, Almeria S (2007) Seroprevalence of Toxoplasma gondii antibodies in wild carnivores from Spain. Vet Parasitol 148:187-192.

https://doi.org/10.1016/j.vetpar.2007.06.038

Sulzner K, Kreuder Johnson C, Bonde RK, Auil Gomez N, Powell J, Nielsen K, Luttrell MP, Osterhaus ADME, Aguirre AA (2012) Health assessment and seroepidemiologic survey of potential pathogens in wild Antillean manatees (Trichechus manatus manatus). PLoS One 7:e44517.

https://doi.org/10.1371/journal.pone.0044517

Torrey EF, Yolken RH (2013) Toxoplasma oocysts as a public health problem. Trends Parasitol 29:380-384.

https://doi.org/10.1016/j.pt.2013.06.001

VanWormer E, Conrad P, Miller M et al (2013b) Toxoplasma gondii, source to sea: higher contribution of domestic felids to terrestrial parasite loading despite lower infection prevalence. EcoHealth 10:277-289. https://doi.org/10.1007/s10393-013-0859-x

VanWormer E, Fritz H, Shapiro K, Mazet JAK, Conrad PA (2013a)

Molecules to modeling: Toxoplasma gondii oocysts at the human-animalenvironment interface. Comp Immunol Microbiol Infect Dis 36:217-231. https://doi.org/10.1016/j.cimid.2012.10.006 